\title{
The use of lacZ marker in enumeration of Azotobacter chroococcum in carrier based inoculants
}

\author{
Manu Solanki ${ }^{1}$, Faquir C. Garg ${ }^{2}$ \\ ${ }^{1}$ Departament of Biotechnology, Manav Rachna International University, Faridabad, India. \\ ${ }^{2}$ Department of Microbiology, SBS Post Graduate Institute, Balawala, Dehradun, Uttarakhand, India.
}

Submitted: August 31, 2012; Approved: September 9, 2013.

\begin{abstract}
A transconjugant of Azotobacter chroococcum Mac 27 tagged with lac Z(A. chroococcum Mac27 L) was found to possess high levels of $\beta$-galactosidase activity constitutively.Further, the lac $\mathrm{Z}$ marker was found to be stably integrated into the chromosome of the A. chroococcum Mac 27 and did not have any adverse effect on growth, nitrogen fixation and excretion of ammonia. A quick method to determine the viable cell number in broth culture and carrier based inoculants has been developed on the basis of $\beta$-galactosidase assay. It was found that there was a direct relationship between the number of cell as determined by standard plate count and intensity of colour that developed upon degradation of ONPG due to $\beta$-galactosidase activity. The method was found to be sensitive enough to determine $1.7 \times 10^{6} \mathrm{CFU} \mathrm{mL}^{-1}$ in broth culture as well as carrier based Azotobacter inoculants. Further, it was observed that when A. chroococcum Mac27 L was inoculated on Brassica campestris, it could be detected in the presence of other bacteria capable of growing on Burks agar medium containing X-gal on the basis of lac $Z$ genetic marker.
\end{abstract}

Key words: $L a c Z$, transconjugant, $\beta$ galactosidase, inoculants, Brassica campestris.

\section{Introduction}

In recent days the importance of Azotobacter chroococcum as a biofertilizer to improve crop productivity of non-leguminous crops has been recognized. These inoculants have been found to increase the yield of rice, wheat, pearl millet, sorghum, maize, cotton, oil seeds and several vegetable crops (Pandey and Kumar, 1989; Lakshminarayana et al., 1992; Paul et al., 2011). In India carrier based inoculants are produced by State Agricultural Universities and private entrepreneurs, however, the crop responses are not consistent under different agro-climatic conditions. Quality of the inoculants and their survival and persistence under field conditions are two major problems associated with beneficial effects of inoculants. Many studies have been conducted to monitor and identify the inoculated strains under field conditions using different techniques. However, information on the survival of strains in carrier based culture packets using methods other than standard plate count technique is lacking. Some of the tech- niques in use to monitor and identify the inoculated strains of bacteria important in agriculture include antibiotic resistance, serological markers, bacteriophage susceptibility, plasmid profile etc. Variation in sensitivity to different antibiotics between species may be a useful taxonomic character for ecological studies and has been used to estimate the survival of fast growing rhizobia from clover and medic growing in non sterile soils (Danso et al., 1973). The disadvantage of antibiotic resistant strains for ecological studies is that selected strains may vary in other important characteristics including ability to fix atmospheric nitrogen. Moreover, loss of antibiotic markers during growth makes this method unsuitable for strain identification. Serological techniques include agglutination, immunogel diffusion, immunofluorescence and ELISA, and have been used to identify Rhizobium japonicum grown in culture and from root nodules (Dudman, 1971; Kishinevsky and Bar Joseph, 1978; Olsen and Rice, 1989).However, cross reactive antigens present in other strains give faulty results and limit the

Send correspondence to M. Solanki. Departament of Biotechnology, Manav Rachna International University, Faridabad, India. E-mail: solankimanu.fet@mriu.edu.in. 
use of these techniques (Vincent and Humphery, 1970). Susceptibility of a certain bacterial strain to a particular bacteriophage forms the basis for phage typing. Bacteriophage typing has been used for screening an individual isolate from most other strains of diverse origins with sufficient sensitivity. However, the phage typing system has limited applications because bacteriophages for all the strains are not available and some phages have wide host range. The DNA-DNA hybridization and plasmid profiles have been used to fingerprint strains of Gram-negative bacteria (Boyce and Morter, 1986; Cooper et al., 1987; Saano and Lindstorm, 1990). However when the strains contain the same number of plasmids with slight detectable differences in electrophoretic migration pattern, differentiation between strains may be difficult.

Marker genes like lac Z, gus A, luc and $g f p$ have been introduced to soil bacteria to identify these bacteria in rhizospheric soil, nodule and within the plant. (De Weger et al., 1991; Bhatia et al., 2002; Kundu et al., 2006; Sunita et al., 2010). These methods are highly specific in identification of introduced bacteria. In the present investigation lac $\mathrm{Z}$ marked strain of $A$. chroococcum was used to develop a method to enumerate viable cells of $A$. chroococcum in broth culture and charcoal based inoculants on the basis of $\beta$-galactosidase activity.

\section{Material and Methods}

\section{Bacterial Cultures and growth media}

Bacterial cultures(Azotobacter chroococcum Mac 27 and lac $Z$ transconjugant, Azotobacter chroococcum Mac $27 \mathrm{~L}$ ) used were from the culture collection of Department of Microbiology, CCSHAU, Hisar. These were maintained on Burks medium (Newton et al., 1953) slants. X-gal (5bromo-4-chloro-3-indolyl- $\beta$-D-galactopyranoside) was added to precooled sterilized medium.

\section{Growth of $A$. chroococcum Mac27 and Mac $27 \mathrm{~L}$ on different carbon sources}

Plates of Burk's agar medium were prepared using different organic compounds as sole source of carbon. The carbon sources - xylose, raffinose, fructose, galactose, glucose, sucrose, lactose and ethanol were used at a concentration of $2 \%$ while butanol, mannitol, polyethylene glycol, sodium acetate, sodium pyruvate, sodium malate, sodium oxalate, calcium gluconate, calcium lactate, potassium citrate, potassium tartarate and resorcinol were added at the concentration of $1 \%$.

\section{Determination of nitrogenase activity}

Slants of Burk's medium with and without $\mathrm{NH}_{4} \mathrm{Cl}$ (2 mM,5 mM, $10 \mathrm{mM}$ and $15 \mathrm{mM}$ ) and yeast extract $(0.05 \% .0 .1 \%$ and $0.2 \%)$ were prepared. Four slants of each treatment were inoculated with pure cultures of $A$. chroococcum Mac 27 and A. chroococcum Mac 27 L sepa- rately. The tubes were incubated for 2 days at $30{ }^{\circ} \mathrm{C}$ in a BOD incubator. Reduction of acetylene to ethylene was determined in gas liquid chromatogtaph. Nitrogenase activity is expressed in terms of $n$ moles of $\mathrm{C}_{2} \mathrm{H}_{4}$ evolved $24 \mathrm{~h}^{-1} \mathrm{mg}^{-1}$ dry weight of cells.

\section{Ammonia excretion}

Ammonia excretion ability of $A$. chroococcum Mac 27 and $A$. chroococcum Mac27 L was studied by growing the cultures in duplicate in $100 \mathrm{~mL}$ Burk's broth. The flasks were incubated for 20 days at $30^{\circ} \mathrm{C}$ in an incubator under stationary conditions. Aliquots of culture broth $(5 \mathrm{~mL})$ were removed at regular intervals of four days, centrifuged at $10,000 \mathrm{rpm}$ for $20 \mathrm{~min}$ and ammonia released in the supernatant was determined using the method of Chaney and Marbach (1962).

\section{Stability of lac Z marker}

A. chroococcum Mac 27, the parent and the transconjugant Mac $27 \mathrm{~L}$ were transferred repeatedly on Burk's medium slants with and without kanamycin. The slants were incubated at $30^{\circ} \mathrm{C}$ in a BOD incubator. After 50 days, all the slants were restreaked on fresh slants and allowed to grow for $48 \mathrm{~h}$ at $30^{\circ} \mathrm{C}$.A loopful of the culture from the freshly streaked slants as well as from the old slants was suspended in $5 \mathrm{~mL}$ phosphate buffer(pH 7.0) and $\beta$-galactosidase activity was determined by microtitre method using ONPG as the substrate.

\section{Assay of $\beta$ galactosidase activity}

One $\mathrm{mL}$ actively growing broth culture of $A$. chroococcum Mac $27 \mathrm{~L}$ was taken in Eppendorf tube and centrifuged at $8000 \mathrm{~g}$ for $10 \mathrm{~min}$. The cell pellet was washed twice with phosphate buffer and resuspended in $500 \mu \mathrm{L}$ of phosphate buffer (pH 7.0). The cells were permeabilized by vortexing for $10 \mathrm{~s}$ with a solution containing $25 \mu \mathrm{L}$ of toluene. To $100 \mu \mathrm{L}$ of permeabilized cells, $10 \mu \mathrm{L}$ ONPG was added. The reaction mixture was incubated at $37^{\circ} \mathrm{C}$ in water bath till the development of yellow colour. Reaction was stopped by adding $2 \mathrm{~mL}$ of $0.4 \mathrm{M} \mathrm{Na}_{2} \mathrm{CO}_{3}$ solution. Colour intensity was determined at $420 \mathrm{~nm}$ using a spectrophotometer against a blank containing all ingredients except the cell culture. $\beta$-galactosidase activity is expressed as Millers unit (Miller, 1972) calculated as per formula given below:

$$
\text { Millers unit }=\frac{\text { Absorbance }_{420}}{\text { Absorbance }_{420} \times T \times V} \times 1000
$$

where $T=$ time of reaction ( $\mathrm{min}$ ) and $V=$ volume of the cell culture used $(\mathrm{mL})$.

\section{Preparation of charcoal based inoculants}

Fifty grams of fine wood charcoal powder was weighed in polypropylene bags and $2 \mathrm{~mL}$ water was added 
into each packet. The packets were sterilized by autoclaving at $15 \mathrm{psi}$ for $30 \mathrm{~min}$ for two consecutive days. To each of these packets, $30 \mathrm{~mL}$ freshly grown broth culture of A.chroococcum Mac 27 and Mac $27 \mathrm{~L}$ were inoculated and incubated at $30^{\circ} \mathrm{C}$.

\section{Enumeration of $A$. chroococcum Mac $27 \mathrm{~L}$ by standard plate count (SPC) and by $\beta$-galactosidase assay}

Five gram of charcoal was added in $45 \mathrm{~mL}$ of phosphate buffer and the flask was agitated intermittently on a vortex shaker for about $30 \mathrm{~min}$. One $\mathrm{mL}$ sample was withdrawn from this flask and serially diluted upto $10^{-5}$. The dilutions ranging from $10^{-3}$ to $10^{-5}$ were spread on Burks agar medium containing $\mathrm{X}$-gal and incubated at $30^{\circ} \mathrm{C}$ in a BOD incubator for $72 \mathrm{~h}$. For enumeration of $\mathrm{A}$. chroococcum Mac $27 \mathrm{~L}$ by chromogenic method, five $\mathrm{mL}$ samples of charcoal based culture suspended in phosphate buffer were withdrawn and centrifuged at $4500 \mathrm{rpm}$ to settle down the charcoal. $\beta$-galactosidase activity was assayed directly in the supernatant by adding ONPG as the substrate after permeabilizing the cells with toluene.

Enumeration of $A$. chroococcum Mac 27 lac $Z$ from the rhizoplane of Brassica campestris.

Surface sterilized seeds (10 g) of Brassica campestris were inoculated with about $10^{8}$ cells of Azotobacter chroococcum Mac 27, A.chroococcum Mac 27 L and HT54. Seeds were sown in pots containing $5 \mathrm{~kg}$ unsterilized soil. Each treatment was replicated three times. After 30 and 60 days of growth, four plants in three replicates were taken out and cut at the crown after removing the adhering soil. These roots were added to $100 \mathrm{~mL}$ sterilized phosphate buffer and vortexed for $15 \mathrm{~min}$. The appropriate serial dilutions were plated on Burks medium plates with and without $\mathrm{X}$-gal. The plates were incubated for $48 \mathrm{~h}$ and the number of colonies that appeared on both types of media was counted.

\section{Results}

\section{Growth pattern of $A$. chroococcum}

The growth of both the strains was compared by using different organic compounds as the sole source of carbon (Table 1). Both A. chroococcum Mac 27, the parent as well as lac $\mathrm{Z}$ marked transconjugant showed good growth on all the substrates tested except xylose, lactose, resorcinol,sodium malate and polyethylene glycol.

\section{Excretion of ammonia by $A$. chroococcum Mac 27} and the transconjugant Mac $27 \mathrm{~L}$

The excretion of ammonia by $A$. chroococcum Mac 27 , and a lac Z marked transconjugant was determined under stationary conditions. Whereas, there was no ammonia excretion either by the parent or the transconjugant derived
Table 1 - Growth of A. chroococcum on various organic compounds.

\begin{tabular}{|c|c|c|c|}
\hline Sr. No. & $\begin{array}{l}\text { Carbon source } \\
\text { (organic) }\end{array}$ & $\begin{array}{l}\text { A. chroococcum } \\
\text { Mac } 27\end{array}$ & $\begin{array}{l}\text { A. chroococcum } \\
\text { Mac } 27 \mathrm{~L}\end{array}$ \\
\hline 1 & Control & - & - \\
\hline 2 & Xylose & - & - \\
\hline 3 & Raffinose & + & + \\
\hline 4 & Fructose & + & + \\
\hline 5 & Galactose & + & + \\
\hline 6 & Glucose & + & + \\
\hline 7 & Sucrose & + & + \\
\hline 8 & Lactose & - & - \\
\hline 9 & Ethanol & + & + \\
\hline 10 & Butanol & + & + \\
\hline 11 & Mannitol & + & + \\
\hline 12 & Polyethylene glycol & - & - \\
\hline 13 & Sodium acetate & + & + \\
\hline 14 & Sodium pyruvate & + & + \\
\hline 15 & Sodium malate & - & - \\
\hline 16 & Calcium oxalate & + & + \\
\hline 17 & Calcium gluconate & + & + \\
\hline 18 & Calcium lactate & + & + \\
\hline 19 & Potassium citrate & - & - \\
\hline 20 & Potassium tartarate & - & - \\
\hline 21 & Resorcinol & - & - \\
\hline
\end{tabular}

from it at the start of the experiment, the excretion of upto $4 \mu \mathrm{g}$ of ammonia $\mathrm{mL}^{-1}$ of broth culture was observed after four days that increased upto twelfth day to $17 \mu \mathrm{g}$ of ammonia $\mathrm{mL}^{-1}$ in both the cultures (Table 2). The quantity of ammonia excreted decreased after sixteenth day and no ammonia excretion was observed after 24 days. It was observed that maximum amount of ammonia was excreted during the stationary phase of growth.

\section{Nitrogenase activity}

The nitrogenase activity expressed as $\mathrm{n}$ moles $\mathrm{C}_{2} \mathrm{H}_{4}$ evolved $\mathrm{h}^{-1} \mathrm{mg}^{-1}$ dry weight of cell was found to be 281.3

Table 2 - Ammonia excretion* by Azotobacter chroococcum Mac 27 and Mac $27 \mathrm{~L}$ at $30{ }^{\circ} \mathrm{C}$ under stationary conditions.

\begin{tabular}{lcc}
\hline Time of Sampling (days) & $\begin{array}{c}\text { A. chroococcum } \\
\text { Mac 27 }\end{array}$ & $\begin{array}{c}\text { A. chroococcum } \\
\text { Mac 27 L }\end{array}$ \\
\hline 0 & 0.00 & 0.00 \\
4 & 4.05 & 3.75 \\
8 & 6.26 & 5.82 \\
12 & 17.00 & 16.60 \\
16 & 5.62 & 5.36 \\
20 & 2.55 & 2.31 \\
\hline
\end{tabular}

*Ammonia produced is expressed in $\mu \mathrm{g} \mathrm{mL}^{-1}$. 
units and 300 units in the parent and transconjugant respectively in the absence of combined nitrogen. When the Burks medium was supplemented with organic nitrogen added in the form of yeast extract from $0.05 \%$ to $0.2 \%$, the nitrogenase activity decreased in both the strains. When Burks medium was supplemented with ammoniacal nitrogen varying from $2 \mathrm{mM}$ to $15 \mathrm{mM}$, nitrogenase activity upto 115.3 and 134 units was observed in A. chroococcum Mac 27 and transconjugant respectively. Nitrogenase activity was completely suppressed in the presence of $5 \mathrm{mmM}$ or more of ammoniacal nitrogen (Table 3).

\section{Determination of stability of lac marker in $A$. chroococcum Mac $27 \mathrm{~L}$}

To check, if the lac $\mathrm{Z}$ marker present in $A$. chroococcum Mac $27 \mathrm{~L}$ was stable or lost during growth in the presence or absence of kanamycin, the culture was transferred every alternate day for 50 days and $\beta$-galactosidase activity was determined in all the twenty four transfers by chromogenic method using ONPG as the substrate (Table 4 ). Though the $\beta$-galactosidase activity varies in different transfers but it was present even after twenty four transfers.

\section{Enumeration of $A$. chroococcum Mac $27 \mathrm{~L}$ in pure culture and in charcoal based culture packets}

A. chroococcum Mac $27 \mathrm{~L}$ strain was grown in Burks medium in the presence of kanamycin for $72 \mathrm{~h}$. The cells were centrifuged and washed using phosphate buffer. Cell suspensions of different concentrations varying from 0.02 to 0.5 were prepared by dilution in the phosphate buffer under aseptic conditions. Aliquots of $200 \mu \mathrm{L}$ of cell suspension were withdrawn from each dilution in triplicate and colour was developed using ONPG as the substrate af-

Table 3 - Effect of combined nitrogen on the nitrogenase activity of $A$. chroococcum Mac 27 and Mac $27 \mathrm{~L}$.

\begin{tabular}{|c|c|c|}
\hline \multirow[t]{3}{*}{ Treatment } & \multicolumn{2}{|c|}{ Strain } \\
\hline & Mac 27 & $\operatorname{Mac} 27 \mathrm{~L}$ \\
\hline & Nitrogenase activity* & \\
\hline Burks Medium(BM) & 281.3 & 300 \\
\hline \multicolumn{3}{|l|}{$\mathrm{BM}+$ Yeast extract } \\
\hline $0.05 \%$ & 180.6 & 188.5 \\
\hline $0.1 \%$ & 166.4 & 169.0 \\
\hline $0.2 \%$ & 145.5 & 136.0 \\
\hline \multicolumn{3}{|l|}{$\mathrm{BM}+\mathrm{NH}_{4} \mathrm{Cl}$} \\
\hline $2 \mathrm{mM}$ & 115.3 & 134.0 \\
\hline $5 \mathrm{mM}$ & 6.5 & 19.5 \\
\hline $10 \mathrm{mM}$ & 0.0 & 0.0 \\
\hline $15 \mathrm{mM}$ & 0.0 & 0.0 \\
\hline
\end{tabular}

*nm $\mathrm{C}_{2} \mathrm{H}_{4}$ evolved $24 \mathrm{~h}^{-1} \mathrm{mg}^{-1}$ dry wt. of the cell. Average value of 4 replications. ter permeabilizing the cells with toluene. The intensity of the colour after 15 min was determined by using a spectrophotometer. Viable number of cells was also determined in all the six dilution by plating appropriate dilutions of each suspension on Burk's medium plates containing kanamycin in duplicate. The viable number of cells was determined after $72 \mathrm{~h}$ of growth. Correlation between the intensity of colour and viable number of cells is represented in Table 5.

There is almost a linear relationship between the intensity of colour due to $\beta$-galactosidase activity and number of viable cells. The method is sensitive and cell number upto $1.7 \times 10^{6}$ can be determined by calorimetric method and cells upto $3.9 \times 10^{6}$ and more can be estimated by visual observations. The number of viable cells in charcoal based inoculants determined by using this chromogenic technique was found to be similar to those determined by standard plate count (SPC) technique (Table 6).

Table 4 - Effect of repeated transfer of A. chroococcum Mac $27 \mathrm{~L}$ on $\beta$-galactosidase activity.

\begin{tabular}{|c|c|c|c|}
\hline \multirow{2}{*}{$\begin{array}{l}\text { Transfer } \\
\text { No. }\end{array}$} & \multirow{2}{*}{$\begin{array}{l}\text { Incubation } \\
\text { time (days) }\end{array}$} & \multicolumn{2}{|c|}{$\beta$-galactosidase Activity(M.U.) } \\
\hline & & Burk's Medium & $\begin{array}{c}\text { Burk's Medium }+ \\
\text { Kanamycin }\end{array}$ \\
\hline 1 & 49 & 22300 & 15120 \\
\hline 2 & 47 & 23300 & 13060 \\
\hline 3 & 45 & 16200 & 19600 \\
\hline 4 & 43 & 14700 & 19100 \\
\hline 5 & 41 & 12710 & 17320 \\
\hline 6 & 39 & 15100 & 18060 \\
\hline 7 & 37 & 13500 & 15500 \\
\hline 8 & 35 & 18100 & 15500 \\
\hline 9 & 33 & 10300 & 9500 \\
\hline 10 & 31 & 17400 & 13300 \\
\hline 11 & 29 & 16300 & 10200 \\
\hline 12 & 27 & 15400 & 7700 \\
\hline 13 & 25 & 14200 & 8700 \\
\hline 14 & 23 & 86400 & 9200 \\
\hline 15 & 21 & 13600 & 14900 \\
\hline 16 & 19 & 93500 & 15400 \\
\hline 17 & 17 & 13900 & 14700 \\
\hline 18 & 15 & 5140 & 12640 \\
\hline 19 & 13 & 9330 & 8200 \\
\hline 20 & 11 & 16100 & 4220 \\
\hline 21 & 9 & 10400 & 3010 \\
\hline 22 & 7 & 16370 & 7380 \\
\hline 23 & 5 & 14710 & 4190 \\
\hline 24 & 3 & 15100 & 4090 \\
\hline
\end{tabular}




\section{Effect of the other bacteria on the $\beta$-galactosidase activity of Mac $27 \mathrm{~L}$}

$\beta$-galactosidase activity of $A$. chroococcum Mac $27 \mathrm{~L}$ was determined in the presence and absence of some of the common soil bacteria in different proportions. The $\beta$-galac-

Table 5 - Enumeration of A. chroococcum Mac $27 \mathrm{~L}$ in pure culture.

\begin{tabular}{lcccc}
\hline $\begin{array}{l}\text { Absorbance } \\
(600 \mathrm{~nm})\end{array}$ & $\begin{array}{c}\text { Absorbance } \\
(420 \mathrm{~nm})\end{array}$ & Viable count & M.U & $\begin{array}{c}\text { Colour inten- } \\
\text { sity (visual) }\end{array}$ \\
\hline 0.015 & 0.018 & $1.7 \times 10^{6}(6.23)$ & 4460 & - \\
0.036 & 0.047 & $3.9 \times 10^{6}(6.59)$ & 4850 & + \\
0.133 & 0.0192 & $1.5 \times 10^{7}(7.17)$ & 5360 & + \\
0.267 & 0.403 & $3 \times 10^{7}(7.47)$ & 5600 & + \\
0.444 & 0.695 & $4.8 \times 10^{7}(7.68)$ & 5810 & + \\
0.558 & 0.893 & $6.8 \times 10^{7}(7.83)$ & 5940 & + \\
\hline
\end{tabular}

*Values in the parentheses represents the log number of viable cells.

Table 6 - Enumeration of $A$. chroococcum Mac $27 \mathrm{~L}$ in charcoal based culture packets.

\begin{tabular}{lcc}
\hline $\begin{array}{l}\text { Time of sampling } \\
\text { (days) }\end{array}$ & No. of cells (SPC) & No. of cells (calculated) \\
\hline 0 & $1.2 \times 10^{7}$ & $1.3 \times 10^{7}$ \\
7 & $10^{7}$ & $1.1 \times 10^{7}$ \\
14 & $3 \times 10^{6}$ & $2.4 \times 10^{6}$ \\
21 & $10^{6}$ & $9 \times 10^{5}$ \\
28 & $4 \times 10^{5}$ & $7 \times 10^{5}$ \\
42 & $2 \times 10^{4}$ & N.D. \\
56 & $10^{3}$ & N.D. \\
\hline
\end{tabular}

tosidase activity was found to be $11000-12000 \mathrm{MU}$ in the presence or absence of other bacteria (Table 7).

\section{Enumeration of $A$. chroococcum Mac $27 \mathrm{~L}$ from the rhizoplane of Brassica campestris}

The transconjugant of A.chroococcum Mac 27 containing the lac $Z$ fusion was used to monitor its survival in the rhizoplane of Brassica campestris. The transconjugant was detected by direct plating on Burks medium containing $\mathrm{X}$-gal. Colonies that appeared blue on these plates were formed by lacZ tagged transconjugant. It was observed that out of $1.2 \times 10^{6} \mathrm{cfu} / \mathrm{plant}$ root, $2.5 \times 10^{5} \mathrm{cfu} / \mathrm{plant}$ root were that of A.chroococcum Mac $27 \mathrm{~L}$ after 30 days of sowing in plants treated with A.chroococcum Mac 27 L (Table 8). However no blue coloured colony was observed in other treatments.

\section{Discussion}

There are around 169 bio-fertilizer production units in India with the capacity to produce 67 thousand tons of

Table 8 - Enumeration of different strains of Azotobacter from the rhizoplane of Brassica campestris.

\begin{tabular}{lccc}
\hline \multirow{2}{*}{$\begin{array}{l}\text { Time of sam- } \\
\text { pling (days) }\end{array}$} & $\begin{array}{c}\text { Treatment } A \\
\text { chroococcum }\end{array}$ & \multicolumn{2}{c}{ cfu/plant/root } \\
\cline { 3 - 4 } 30 & Mac 27 L & $1.2 \times 10^{6}$ & $2.5 \times 10^{5}$ \\
& Mac 27 & $1.55 \times 10^{6}$ & - \\
& HT-54 & $4.2 \times 10^{6}$ & - \\
60 & Control & $10^{7}$ & \\
& Mac 27 L & $1.2 \times 10^{5}$ & $2.0 \times 10^{4}$ \\
& Mac 27 & $1.3 \times 10^{5}$ & - \\
\hline
\end{tabular}

Table 7 - $\beta$-Galactosidase activity of $A$. chroococcum Mac $27 \mathrm{~L}$ as affected by other bacteria.

\begin{tabular}{|c|c|c|c|c|}
\hline \multirow[t]{2}{*}{ Culture } & \multicolumn{2}{|c|}{ Cell concentration $(600 \mathrm{~nm})$} & \multicolumn{2}{|c|}{ Colour intensity } \\
\hline & Mixed Culture & Lac Z marked & Absorbance $(420 \mathrm{~nm})$ & M.U. \\
\hline Mac 27 & 1.25 & - & 0.011 & - \\
\hline Mac $27 \mathrm{~L}$ & 1.20 & 1.20 & 1.0 & 11700 \\
\hline Mac $27+\operatorname{Mac} 27 \mathrm{~L}(1: 1)$ & 1.22 & 0.61 & 0.49 & 11300 \\
\hline Mac $27+\operatorname{Mac} 27$ L(4:1) & 1.28 & 0.256 & 0.215 & 11800 \\
\hline Bacillus & 1.482 & - & 0.016 & - \\
\hline Mac 27 L+ Bacillus (1:1) & 1.33 & 0.665 & 0.56 & 11900 \\
\hline Mac 27 L+ Bacillus (1:4) & 1.46 & 0.292 & 0.24 & 11600 \\
\hline Pseudomonas & 0.95 & - & 0.017 & - \\
\hline Mac $27 \mathrm{~L}+$ Pseudomonas $(1: 1)$ & 1.1 & 0.55 & 0.47 & 12000 \\
\hline Mac 27 L+ Pseudomonas (1:4) & 1.0 & 0.2 & 0.17 & 12000 \\
\hline Mac 27 L + Pseudomonas + Bacillus $(1: 1: 1)$ & 0.96 & 0.32 & 0.27 & 11900 \\
\hline Mac 27 L + Pseudomonas + Bacillus (1:2:2) & 0.9 & 0.18 & 0.15 & 11900 \\
\hline Mac 27 L + Bacillus (1:9) & 1.026 & 0.103 & 0.072 & 11400 \\
\hline
\end{tabular}


biofertilizers, current annual production is over 20 thousand tons.However, because of lack of quick and reliable methods to determine the quality of these bioferlizers, some of the biofertilizers being produced by these agencies may be of poor quality. Thus there is a need to develop a reliable, rapid and reproducible method for enumeration of viable number of cells in these inoculants which is one of the major indicator of quality of inoculants.Drahos et al. (1986) developed a marker system based on expression of $E$. coli lac operon genes into Pseudomonas fluorescens enabling them to cleave the chromogenic substrate 5-bromo 4-chloro-3-indolyl- $\beta$-D galactopyranoside (X-gal) to a coloured compound. A lac $\mathrm{Z}$ marked transconjugant of $A$. chroococcum Mac 27 developed earlier in for ecological studies (Garg, unpublished) was used in the present investigation. Although insertion of the transposon does not alter the eological behavior of the host but in some transconjugants the marker have been found to be inserted into some essential genes (Sessitsch et al., 1997). To determine if lac $\mathrm{Z}$ insertion into A. chroococcum Mac 27 has resulted in loss of any other metabolic property of the parent, the characteristics like growth pattern, utilization of different carbon sources, nitrogenase activity and excretion of ammonia of lac Z marked A. chroococcum were studied and it was observed that the insertion of the lac $\mathrm{Z}$ containing transposon has not damaged any of the essential property of the A.chroococcum Mac 27, the parent and the present strain can be reliably used as biofertilizer for various non leguminous crops. Hofte et al. (1990) constructed a lac Z marked strain of Pseudomonas aeruginosa and a detailed comparison was made between the wild type strain $7 \mathrm{NSK} 2$ and the lac $Z$ marked strain MPB1. The results showed that none of the genes essential for growth, siderophore production, survival, plant growth stimulation or root colonization had been damaged in the MPB1 strain.

Further, this marker can be used effectively for monitoring of $A$. chroococcum Mac $27 \mathrm{~L}$ in the environment since lac $\mathrm{Z}$ insertion is found to be stable as confirmed by repeated and successive transfers on Burks medium slants with and without kanamycin.Similar observations have also been reported by Pal et al. (2000) in case of lac Z marked Pseudomonas glumae.In the present study, it has been found that $\beta$-galactosidase activity of lac $\mathrm{Z}$ marked strain of $A$. chroococcum Mac 27 is directly proportional to the cell concentration. After establishing a direct relationship between cell concentration and the intensity of the colour developed by the cleavage of chromogenic substrate o-nitrophenyl- $\beta$-D-galactopyranoside (ONPG) due to $\beta$ galactosidase activity, it was presumed that this property may be useful in enumeration of lac $\mathrm{Z}$ tagged strain of $A$. chroococcum either in pure culture or carrier based inoculants. When the number of viable cells in charcoal based inoculants was determined by using this chromogenic technique, the number of cells in suspension was found to be similar to those determined by standard plate count. These results confirmed our hypothesis that number of cells can be determined by measuring the intensity of the colour that appear due to $\beta$-galactosidase activity in the lacZ tagged $A$. chroococcum Mac 27. Further, lac Z marked A. chroococcum was used to monitor its survival in the rhizoplane of Brassica campestris. However there are a variety of contaminants present in the environment which may interfere in the expression of $\beta$ galactosidase activity of the transconjugant. That the contaminants do not affect the $\beta$-galactosidase activity of $A$. chroococcum Mac $27 \mathrm{~L}$ has been confirmed by determining the $\beta$-galactosidase activity of $A$. chroococcum Mac $27 \mathrm{~L}$ in the presence and absence of some of the common soil bacteria in different proportions. There was no effect on the expression of $\beta$-galactosidase activity of the transconjugant by the presence of Bacillus spp. in concentration as high as 10 times that of A.chroococcum Mac $27 \mathrm{~L}$. The lac $Z$ marked transconjugant has been found to be reliable for the enumeration of number of viable cells in culture packets, this has great practical application for quality control of microbial inoculants as well as proving a strain for ecological studies.

\section{References}

Bhatia R, Dogra RC, Sharma PK (2002) Construction of green fluorescent protein (GFP)-marked strains of Bradyrhizobium for ecological studies. J Appl Microbiol 93:835-839.

Boyce JR, Morter RL (1986) Plasmid profile analysis of bovine isolates of Pasteurella haemolytica. American J Vety Research 47:1204-1206.

Chaney AL, Marbach EP (1962) Modified reagents for the determination of urea and ammonia. Clin Chem 8:130-132.

Cooper JE, Bjourson AJ, Thompson JK (1987) Identification of Lotus rhizobia by direct DNA hybridization of crushed root nodules. Appl Environ Microbiol 53:1705-1707.

Danso SK, Habte, M Alexander, M (1973). Estimating the density of individual bacterial populations introduced into natural ecosystems. Can J Microbiol 19, 1450-1451.

De Weger LA, Dunbar P, Mahafee WF, Lugtenberg BJJ, Sayler GS (1991) Use of bioluminescence markers to detect Pseudomonas spp. in the rhizosphere. Appl Environ Microbiol 57:3641-3644.

Drahos DJ, Hemming BC, Mc Pherson S (1986). Tracking recombinant organisms in the environment: $\beta$ galactosidase as a selectable non-antibiotic marker for fluorescent Pseudomonads. Biotechnology 4:439-444.

Dudman WF (1971) Antigenic analysis of Rhizobium japonicum by immunodiffusion. Appl Microbiol 21:973-985.

Hofte M, Mergeay M, Verstraete W (1990) Marking the rhizopseudomonas strain $7 \mathrm{NSK} 2$ with a $\mathrm{Mu}$ d(lac) element for ecological studies. Appl Environ Microbiol 56:1046-1052.

Kishinevsky B, Bar Joseph M (1978) Rhizobium strain identification of Arachis hypogaea nodules by enzyme linked immunosorbant assay (ELISA). Can J Microbiol 24:1537-1543.

Kundu BS, Nandal K, Tiwari M, Tomar M (2006). Establishment and influence of phosphate solubilizing bacteria on pearl millet. Ind J Plant Physiol 11(2):201-205. 
Lakshminarayana K, Narula N, Hooda IS, Faroda AS (1992) Nitrogen economy in wheat (Triticum aestivum) through use of Azotobacter chroococcum. Ind J Agric Sci 62:75-76.

Miller JH (1972) Experiments in molecular genetics. Cold Spring Harbor Laboratory, Cold Spring Harbor, N.Y.

Newton JW, Wilson PW, Burris RH (1953) Direct demonstration of ammonia as an intermediate in nitrogen fixation by Azotobacter. J Biol Chem 204:445-451

Olsen PE, Rice WA (1989) Rhizobium strain identification and quantification in commercial inoculants by immunoblot analysis. Appl Environ Microbiol 55:520-522.

Pal KK, Tilak KVBR, Saxena AK, Dey R, Singh CS (2000) Monitoring a biocontrol rhizobacterium Pseudomonas glumae using Tn5: : lacZ marker. Ind J Microbiol 40:21-24.

Pandey A, Kumar S (1989) Potential of azotobacters and azospirilla as biofertilzers for upland agriculture: A review. J Sci Indust Res 48:134-144.
Paul S, Rathi MS, Tyagi SP (2011) Interactive effect with AM fungi and Azotobacter inoculated seed on germination, plant growth and yield in cotton (Gossypium hirsutum). Ind $\mathrm{J}$ Agric Sci 81(11):1041-1045.

Sunita S, Kapoor KK, Goyal S, Sharma PK (2010) Establishment of lacZ marked strain of phosphate solubilizing bacterium in the rhizosphere and its effect on plant growth in mungbean. Ind J Microbiol 50:117-121.

Saano A, Lindstrom K (1990) Detection of rhizobia by DNADNA-hybridization from soil samples: Problems and perspectives. Symbiosis 8:61-73

Sessitsch A, Jjemba PK, Hardarson G, Akkermans ADL, Wilson KJ (1997) Measurement of the competitiveness index of Rhizobium tropici strain CIAT899 derivatives marked with the gusA gene. Soil Biol Biochem 29:1099-1110.

Vincent JM, Humphery BA (1970) Taxonomically significant group of antigens in Rhizobium. J Gen Microbiol 63:379382.

All the content of the journal, except where otherwise noted, is licensed under a Creative Commons License CC BY-NC. 